IOSR Journal of Pharmacy

e-ISSN: 2250-3013, p-ISSN: 2319-4219, www.iosrphr.org

Volume 2 Issue 6 || $\mid$ Nov-Dec. 2012 || $\mid$ PP.50-53

\title{
Synthesis of 2-phenyl-5-sulpha/substituted-3- substituted phenyl azo indoles used as antifertility agent
}

\author{
Dharmendra Kumar, Gajendra Singh, Sanjeev Kumar, C. P. Singh* \\ Research Division, Dept. of Chemistry, Sahu Jain College, Najibabad, (UP) 246763, India
}

\begin{abstract}
A novel series of 2-phenyl-5-sulpha/substituted-3-phenyl substituted azo indoles have been synthesized and tested as an antifertility activity in mature albino mice. The tested compounds showed significant antifertility activity.
\end{abstract}

Keywords-Synthesis, Antifertility activity, Indore, Azo indoles, chemical analysis.

\section{INTRODUCTION}

The population explosion is one of the major problems of present era in the world. The increment of population raises so many sufferings like lack of food, water, energy and raw material supply, decline in mortality etc. before human being and it also has increased the life expectancy. In view of above discussion, scientists have started to tackle this serious problem by developing the effective contraceptives.

The term contraceptives refers to those chemical substances that inhibit either the sperms production and sperm motility in males or prevent the formation of ovum and produce some changes in the endometrium, rendering it non-receptive to a fertilized ovum in females [1].

The only practical method available today for the chemical contraception is the "pill" which consist of a progestagen along with a low dose of an estrogen. Prostaglandins and naturally occurring estrogen, which are steroidal in nature, can be used as anti-implantation agents. The requirement if successful oral contraceptives [2] are stringent, for it will be used millions of healthy people. It must therefore be extremely safe as well as highly efficient and its action must be quickly and completely reversible, even after years of continuous use. The fact that alternative methods are less reliable implies that there use will lead to more unwanted pregnancies with their attendant convenience, morbidity and mortality.

Dodds [3] demonstrated estrogenic activity in diethyl stilbestrol (DES) and since then a large variety of non-steroidal structural compounds have been shown to posses varying degree of activity [4]. Inspite of the remarkable efficacy of these steroidal preparations, the continuous administration of these causes serious disorders such as hypertension, myocardial infarction, cancer, jaundice, weight gain etc. Therefore, there is a continue interest in the development of non-steroidal anti-fertility active heterocyclic compounds.

Indoles are one of the most important nitrogen containing heterocyclic molecules. The indole nucleus is important substructures found in numerous natural or synthetic alkaloids [5, 6]. One of the naturally occurring indoles, tryptophan, has a high sensitivity of tryptophyl residue in proteins and oxidation of tryptophan has been implicated in the photo degradation and photo yellowing of wool [7]. The biological and chemical significance of indole and its derivative have been widely reported in literature. It has been great importance in clinical chemistry. In view of importance of indole chemistry, attempts have been made to synthesise a number of indole derivatives by various scientists. The derivatives of indole have been found in nervous system and claimed responsible for various physiological activity in human system. Hydroxy indoles play a prominent role in the central nervous system and have been reported to product long lasting deptetions of serotonin in brain tissues [811]. Several mono and di hydroxyl derivatives of indole have also been found to play an important role in brain as neurotransmitters. Indenopyridines have been unique pharmacological properties, such as insecticidal, phosphodiesterase inhibiting, antifungal, antispermatogenic, antifertility, antagonistic and ant arrhythmic activities [12]. The diversity of the structure encountered, as well as their biological and pharmaceutical relevance, have motivated research aimed at the development of new economical, efficient and selective synthetic strategies, particularly for the synthesis of substituted indole rings [13,14]. Literature survey however reveals that no work have been done on sulpha/substituted indole and N-phenyl acyl sulpha/substituted azoindoles and their pharmacological activity. It was been considered worthwhile to synthesis N-phenyl acyl sulpha/substituted phenyl amine and their indole derivatives. As part of our on going research on the development of novel synthetic route for biologically active heterocyclic compounds, herein, we report a simple, 
facile procedure for the synthesis of sulpha/substituted phenyl indoles. The newly synthesized indole derivatives were studied for their pharmacological activity such as antifertility.

\section{EXPERIMENTAL SECTION}

Materials

All the substituted phenyl amine, $\alpha$-halo acyl benzene, indole derivatives, and reference compound were purchased from Aldrich Chemicals. Ethanol, glacial acetic acid and all other reagents were purchased from S. D. Fine Chem. Analytical TLC was performed on pre-coated plastic sheets of silica gel G/UV-254 of $0.2 \mathrm{~mm}$ thickness (Macherey-Nagel, Germany).

Synthesis of 2-phenyl-5-sulpha/substituted-3- substituted phenyl azo indoles

Sulpha/substituted phenyl amine was dissolved in $\mathrm{HCl}$, water is added in sufficient amount and cooled to $0^{\circ} \mathrm{C}$. Aqueous solution of sodium nitrite was gradually added to hydrochloride. The diazonium salt solution so obtain was filtered into a well cooled stirred mixture of sodium acetate by and sulpha/ substituted phenyl amino N-phenacyl phenyl amine in ethanol and shaken vigorously, precipitate separate do not filtered, dried and recrystallized from ethanol givining shinning coloured needles of sulpha/substituted phenyl azo substituted phenyl amono N-phencyl phenyl amine.

Sulpha/substituted phenylazo substituted phenyl amino N-phenacyl phenyl amine was dissolved in glycial acetic acid and refluxed on water bath for half an hour on cooling, a crystalline solid compound reported out, which is recrystallzed from ethanol.

Test Animals

Adult's male Wister albino mice, each in the weight range of 180-200gm were used for antifertility testing. They were procured from National Vetniary Research centre, Bareilly, India. The animals were kept in polypropylene cages and housed under standard conditions of temperature, humidity, dark light cycle (12h-12h) and diet. . Before each test, the animals were fasted for at least $12 \mathrm{~h}$.

\section{Experimental Protocol}

Melting points were determined using an open-ended capillary tube method and are uncorrected. The microanalysis of C, H, N, O, S and halogens were estimated by elemental analyzer (Perkin Elmer 2400). The purity of the synthesized compounds was checked by TLC. FT-IR spectra were recorded on a Perkin-Elmer 1605 series FT-IR in a $\mathrm{KBr}$ disc. ${ }^{1} \mathrm{H}$ NMR spectra were recorded at $300 \mathrm{MHz}$ on a Bruker FT-NMR spectrophotometer using TMS as internal standard.

Synthesis of 2-phenyl-5-benzene sulphonamide-3-flourophenylazoindole

A light yellow crystalline powder, mp 171-173 ${ }^{\circ} \mathrm{C}$, yields $65 \%$, molecular formula $\mathrm{C}_{26} \mathrm{H}_{19} \mathrm{FN}_{4} \mathrm{SO}_{2}$, Anal. Calcd for $\mathrm{C}_{26} \mathrm{H}_{19} \mathrm{FN}_{4} \mathrm{SO}_{2}$ (470.52): C, 66.37; H, 4.07; F, 4.04; N, 11.90; S, 6.81; O, 6.80. Found: C, 66.32; $\mathrm{H}, 4.04 ; \mathrm{F}, 4.02 ; \mathrm{N}, 11.87 ; \mathrm{S}, 6.78 ; \mathrm{O}, 6.78$. UV ( $\left.\lambda_{\max }\right) 280$, IR $(\mathrm{KBr}) v_{\max }$ in cm $\mathrm{cm}^{-1} 1325(\mathrm{C}-\mathrm{F}), 760(\mathrm{C}-\mathrm{C}), 1245$ $(\mathrm{C}-\mathrm{N}), 1560\left(\mathrm{C}=\mathrm{C}\right.$ or aromatic ring), $3040(\operatorname{aromatic} \mathrm{C}-\mathrm{H}), 3345(\mathrm{~N}-\mathrm{H}), 1445(\mathrm{~N}=\mathrm{N}), 1153\left(\mathrm{SO}_{2}\right), 3280\left(\mathrm{NH}_{2}\right)$, ${ }^{1} \mathrm{NMR}\left(\mathrm{CDCl}_{3}\right) \delta$ in ppm, $5.9(\mathrm{~b}, 1 \mathrm{H}, \mathrm{NH}), 7.75-6.40(\mathrm{~m}, 16 \mathrm{H}, \mathrm{Ar}-\mathrm{H}), 11.5\left(\mathrm{~b}, 2 \mathrm{H}, \mathrm{SO}_{2} \mathrm{NH}_{2}\right)$.

\section{Synthesis of 2-phenyl-5-benzene sulphonamide-3-chlorophenylroazoindole}

A light yellow crystalline powder, mp $170-172{ }^{\circ} \mathrm{C}$, yields $69 \%$, molecular formula $\mathrm{C}_{26} \mathrm{H}_{19} \mathrm{ClN}_{4} \mathrm{SO}_{2}$, Anal. Calcd for $\mathrm{C}_{26} \mathrm{H}_{19} \mathrm{ClN}_{4} \mathrm{SO}_{2}$ (486.98): C, 64.13; H, 3.93; Cl, 7.28; N, 11.50; S, 6.58; O, 6.57. Found: C, $64.11 ; \mathrm{H}, 3.90 ; \mathrm{Cl}, 7.25 ; \mathrm{N}, 11.49 ; \mathrm{S}, 6.55 ; \mathrm{O}, 6.55$. UV $\left(\lambda_{\max }\right) 277$, IR $(\mathrm{KBr}) v_{\max }$ in cm $^{-1} 670(\mathrm{C}-\mathrm{Cl}), 760(\mathrm{C}-$ C), $1240(\mathrm{C}-\mathrm{N}), 1565(\mathrm{C}=\mathrm{C}$ or aromatic ring), 3045 (aromatic $\mathrm{C}-\mathrm{H}), 3340(\mathrm{~N}-\mathrm{H}), 1445(\mathrm{~N}=\mathrm{N}), 1150\left(\mathrm{SO}_{2}\right)$, $3280\left(\mathrm{NH}_{2}\right),{ }^{1} \mathrm{NMR}\left(\mathrm{CDCl}_{3}\right) \delta$ in ppm, 5.9 (b, 1H, NH), 7.65-6.75 (m, 16H, Ar-H), 11.5 (b, 2H, $\left.\mathrm{SO}_{2} \mathrm{NH}_{2}\right)$.

\section{Synthesis of 2-phenyl-5-benzene sulphonamide-3-nitrophenylazoindole}

A yellow crystalline powder, mp $195-197{ }^{\circ} \mathrm{C}$, yields $72 \%$, Molecular formula $\mathrm{C}_{26} \mathrm{H}_{19} \mathrm{~N}_{5} \mathrm{SO}_{4}$, Anal. Calcd for $\mathrm{C}_{26} \mathrm{H}_{19} \mathrm{~N}_{5} \mathrm{SO}_{4}$ (497.53): C, 62.77; H, 3.85; N, 14.08; S, 6.44; O, 12.86. Found: C, 62.76; H, 3.83; N, 14.07; S, 6.41; O, 12.83. UV ( $\left.\lambda_{\max }\right)$ 277.6, IR $(\mathrm{KBr}) v_{\max }$ in $\mathrm{cm}^{-1} 1600\left(\mathrm{C}-\mathrm{NO}_{2}\right), 760(\mathrm{C}-\mathrm{C}), 1245(\mathrm{C}-\mathrm{N}), 1565$ $(\mathrm{C}=\mathrm{C}$ or aromatic ring), 3055 (aromatic $\mathrm{C}-\mathrm{H}), 3340(\mathrm{~N}-\mathrm{H}), 1445(\mathrm{~N}=\mathrm{N}), 1150\left(\mathrm{SO}_{2}\right), 3280\left(\mathrm{NH}_{2}\right),{ }^{1} \mathrm{NMR}$ $\left(\mathrm{CDCl}_{3}\right) \delta$ in ppm, 5.9 (b, 1H, NH), 7.70-6.75 (m, 16H, Ar-H), 10.5 (b, 2H, $\left.\mathrm{SO}_{2} \mathrm{NH}_{2}\right)$.

\section{Synthesis of 2-phenyl-5-benzene sulphonamide-3-methylphenylazoindole}

A light yellow crystalline powder, mp $178-180{ }^{\circ} \mathrm{C}$, yields $73 \%$, Molecular formula $\mathrm{C}_{27} \mathrm{H}_{22} \mathrm{~N}_{4} \mathrm{SO}_{2}$, Anal. Calcd for $\mathrm{C}_{27} \mathrm{H}_{22} \mathrm{~N}_{4} \mathrm{SO}_{2}$ (466.56): C, 69.51; H, 4.75; N, 12.01; S, 6.87; O, 6.86. Found: C, 69.49; H, 4.72; N, 11.99; S, 6.83; O, 6.85. UV ( $\left.\lambda_{\max }\right) 273$, IR $(\mathrm{KBr}) v_{\max }$ in $\mathrm{cm}^{-1}, 765(\mathrm{C}-\mathrm{C}), 1245(\mathrm{C}-\mathrm{N}), 1555(\mathrm{C}=\mathrm{C}$ or aromatic ring), 3055 (aromatic $\mathrm{C}-\mathrm{H}), 3340(\mathrm{~N}-\mathrm{H}), 1445(\mathrm{~N}=\mathrm{N}), 1150\left(\mathrm{SO}_{2}\right), 3275\left(\mathrm{NH}_{2}\right),{ }^{1} \mathrm{NMR}\left(\mathrm{CDCl}_{3}\right) \delta$ in ppm, 2.25 $\left(\mathrm{t}, 3 \mathrm{H},-\mathrm{CH}_{3}\right), 5.9(\mathrm{~b}, 1 \mathrm{H}, \mathrm{NH}), 7.65-6.75(\mathrm{~m}, 16 \mathrm{H}, \mathrm{Ar}-\mathrm{H}), 10.5\left(\mathrm{~b}, 2 \mathrm{H}, \mathrm{SO}_{2} \mathrm{NH}_{2}\right)$. 


\section{Synthesis of 2-phenyl-5-benzene sulphonamide-3-hydroxyphenylhydroxyazoindole}

A yellow crystalline powder, mp $197-199{ }^{\circ} \mathrm{C}$, yields $68 \%$, molecular formula $\mathrm{C}_{26} \mathrm{H}_{20} \mathrm{~N}_{4} \mathrm{SO}_{3}$, Anal. Calcd for $\mathrm{C}_{26} \mathrm{H}_{20} \mathrm{~N}_{4} \mathrm{SO}_{3}$ (468.53): C, 66.65; H, 4.30; N, 11.96; S, 6.84; O, 10.24. Found: C, 66.63; H, 4.29; N, 11.93; S, 6.81; O, 10.21. UV $\left(\lambda_{\max }\right) 280$, IR $(\mathrm{KBr}) v_{\max }$ in $\mathrm{cm}^{-1} 1305(\mathrm{C}-\mathrm{OH}), 760(\mathrm{C}-\mathrm{C}), 1245(\mathrm{C}-\mathrm{N}), 1560$ $\left(\mathrm{C}=\mathrm{C}\right.$ or aromatic ring), $3040(\operatorname{aromatic} \mathrm{C}-\mathrm{H}), 3345(\mathrm{~N}-\mathrm{H}), 1445(\mathrm{~N}=\mathrm{N}), 1153\left(\mathrm{SO}_{2}\right), 3280\left(\mathrm{NH}_{2}\right),{ }^{1} \mathrm{NMR}$ $\left(\mathrm{CDCl}_{3}\right) \delta$ in ppm, $5.9(\mathrm{~b}, 1 \mathrm{H}, \mathrm{NH}), 4.3(\mathrm{~s}, 1 \mathrm{H}, \mathrm{OH}) 7.75-6.40(\mathrm{~m}, 16 \mathrm{H}, \mathrm{Ar}-\mathrm{H}), 11.5\left(\mathrm{~b}, 2 \mathrm{H}, \mathrm{SO}_{2} \mathrm{NH}_{2}\right)$.

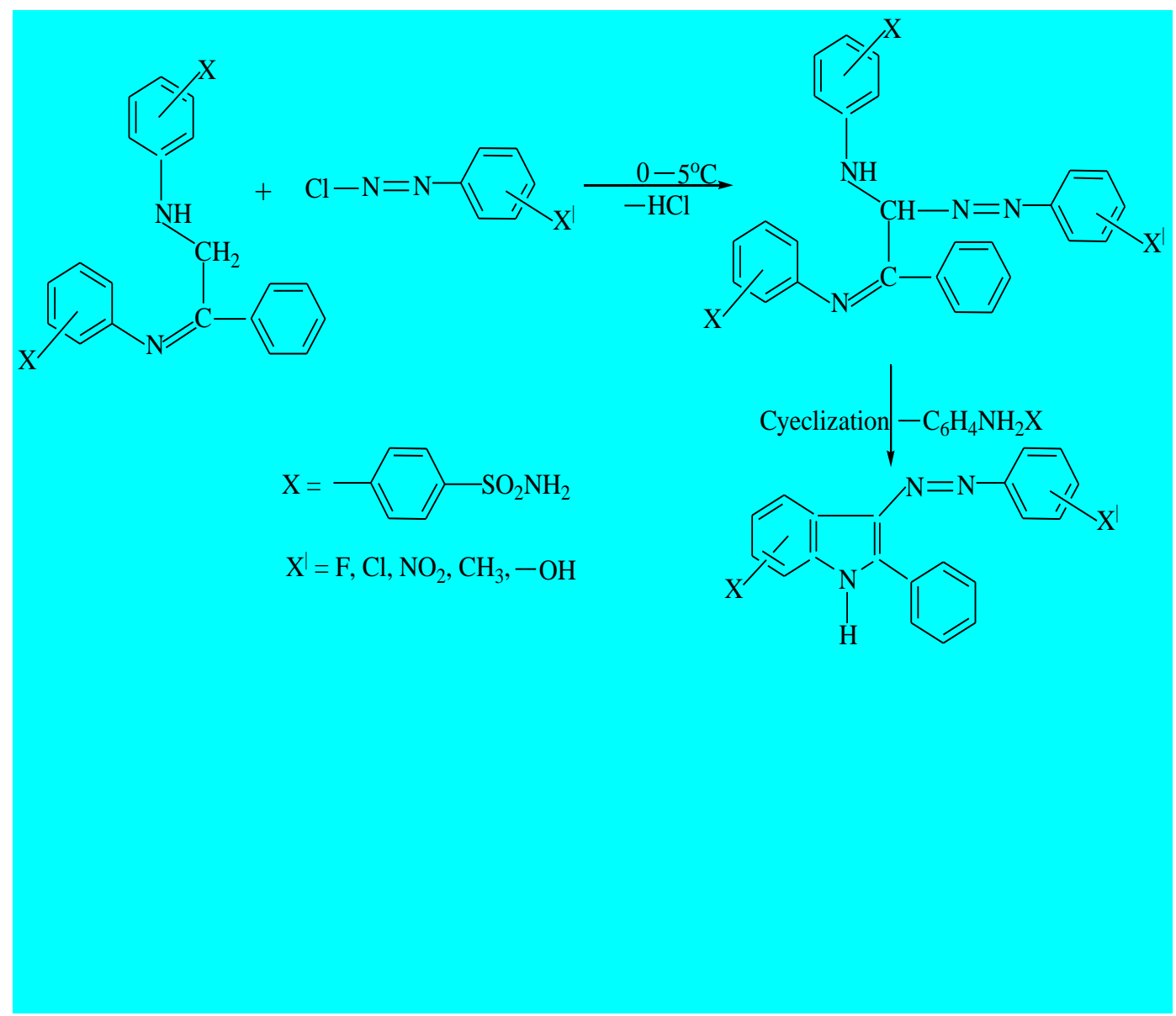

Fig. 1: Synthesis of 2-phenyl-5-sulpha/substituted-3-phenyl substituted azo indoles

\section{RESULTS AND DISCUSSION}

The present studies consist of the synthesis of 2-phenyl-5-sulpha/substituted-3- substituted phenyl azo indoles efficiently. The synthesized compounds of possess useful pharmacological properties as determined by standard test procedures described below. The structures of newly synthesized compounds are clearly supported by their ${ }^{1} \mathrm{H}$ NMR spectra studies and microanalysis. Synthesized 2- phenyl-5-sulpha/substituted-3-substituted phenyl azo indoles were used as antifertility drugs. However, sulpha/substituted indoles have not been investigated. The authors synthesized 2-phenyl-5-sulpha/substituted-3- substituted phenyl azo indoles and tested for the antifertility activity.

\section{ANTIFERTILITY ACTIVITY TEST}

The antifertility activity test technique followed was the same as that described by Malcolm R. Bell et al. (1975). Mature female mice of known fertility was used and medicated daily with the test agent for 6 days after kept overnight with males of proven fertility (a total of six medications). The rats were autopsied 15 days after insemination and their uteri were removed and examined for evidence of pregnancy. The synthesized compounds to be tested were administered either as suspensions, depending on solubility and dosage level, in 10 percent ethyl alcohol. 
The synthesized compounds were found to be effective as antifertility agents. The synthesized compound of 2-phenyl-5-benzene sulphonamide-3-chlorophenylazoindole was found to be best effective as antifertility agents, completely preventing pregnancy when administered orally to mature female rats in the dose range $20 \mathrm{mg} / \mathrm{kg}$ x 6days according to the above method.

\section{CONCLUSION}

The present study revealed that, synthesized compound 2-phenyl-5-benzene sulphonamide-3chlorophenylazoindole possesses significant antifertility activity agents preventing pregnancy when administered orally to mature female rats in the dose range $20 \mathrm{mg} / \mathrm{kg}$ x 6days.

\section{ACKNOWLEDGMENT}

The authors express their sincere thank to Dr. Dhirendra Singh, principal, Sahu Jain College, Najibabad, for providing lab facilities and also thank to CDRI (CSIR) Lucknow, IIT Roorkee for Providing IR, NMR spectral data and pharmacological data.

\section{REFERENCES}

[1]. R. Unny, A. K. Chauhan, Y. C. Joshi, M. P. Dobhal, R. S. Gupta. A review on potentiality of medicinal plants as the source of new contraceptive principles. 2003 (10) 233-260.

[2]. A. Chaudhary, N. Sharma, P. Sharma, N. D. Jasuja, G. Sharma, S. C. Joshi, R. V. Singh. Contraceptive property of nitrogen/oxygen sulfur donor heterocyclic compounds. Rasayn J. Chem. 2008 (3) 648-692.

[3]. E. C. Dodds, L. Goldberg, W. Lawson, Robinson. Estrogenic activity of certain synthetic compounds. Nature 1933 (56) 131.

[4]. A. B. Kar. Non-steroidal antifertility agent interfering with different phases of reproduction in the females. J. Scientific and Ind. Res, 1969 (28) 123.

[5]. R. J. Sundberg. Indoles, Academic Press, London, 1996.

[6]. J. A. Joule, in: E. J. Thomas (Ed.), Science of synthesis, 10, Thieme, Stuttgart, 2001, P. 361.

[7]. J.A.Mclaren, B.Milligan.The chemistry and reactivityof wool fiber.Science press, Marrickville, Australia1981. 220.

[8]. S. J. Victor, H. G. Baumgarten, W. Lovenberg. Depletion of tryptophan hydroxylase by 5,6-dihydroxytryptamine in rat brain, time course and regional differences. J. Neuro. Chem.. 1974 (22) 541

[9]. H. G. Baumgarten, S. J. Victor, W. Lovenberg. Effect of intraventricular in infection of 5,7-dihydroxytryptamines on regional tryptophan hydroxylase in rat brain. J. Neuro. Chem 1973 (21) 251.

[10]. C. P. Singh. A. Kumar, K. Gaurav. H. Hasan. Ultra Sc. Of Phy. 2003 (15) 107-116.

[11]. M. Z. Reham, J. A. Choudhry. Chem. Pharm. Bull. 2006 (54) 8. 1175.

[12]. P. Thirumurugan, P. T. Perumal. $\mathrm{InCl}_{3}$ mediated one-pot synthesis of indol-3-yl pysidine and 2,2'-bipyridine derivatives through multi-component reaction. Tetrahedron 2009 (65) 7620-7629.

[13]. R. J. Sundberg, in: A. R. Katritzky, C. W. Rees (Ed.), Comprehensive Heterocyclic Chemistry, 4, Pergamon, Oxford, 1984, P. 314.

[14]. J. Tois, R. Franzen, A. Koskinen, Tetrahedron 59 (2009) 5395. 